\title{
DEVELOPMEMT OF PILOT SCALE DEALUMINATION UNIT OF 2.5 kg METAKAOLIN PER BATCH CAPACITY
}

\author{
S. G. Bawa ${ }^{1, *}$, A. S. Ahmed ${ }^{2}$, P. C. Okonkwo ${ }^{3}$ and S. M. Waziri ${ }^{4}$

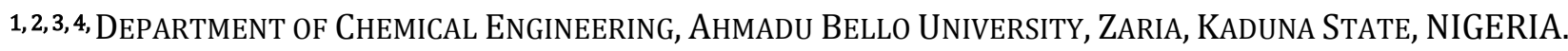 \\ E-mail addresses.1sgbawa@gmail.com, ${ }^{2}$ asahmed2001@yahoo.com, ${ }^{3}$ chemstprom@gmail.com, \\ 4 smwaziri@gmail.com
}

\begin{abstract}
A pilot-size dealumination unit to handle $2.5 \mathrm{~kg}$ of metakaolin per batch was designed and fabricated and test run. The metakaolin was prepared from Kankara kaolin. The metakaolin was completely split into silica and alumina. The silica component which was inert to the sulphuric acid used during the reaction and was obtained as a solid product. While the alumina which reacted with the sulphuric acid was obtained in liquid form as aluminum sulphate, known as alum. The dealumination unit comprises of the dealumination reactor, known as dealuminator, acid holding tank and metakaolin slurry mixing tank. The material of construction selected for the dealumination reactor was stainless steel type 304 lined internally with glass to withstand the corrosive environment of the concentrated sulphuric acid at the reaction temperature $>140^{\circ} \mathrm{C}$. The capacity of the componentsare; acid holding tank 5 liters;metakaolin slurry mixing tank 20 liters, with $70 \mathrm{~W}$ capacity motor and the dealuminator 50 liters, which had pressure relief valve, pressure gauge (0-10 bars) and temperature gauge $\left(0-300^{\circ} \mathrm{C}\right)$ on the cover. Woven glass fiber cloth was used as lagging material to minimize heat lossto the surrounding. The purity level of the silica obtained from the reaction was above 95\%.The endothermic nature of the dealumination process was void of external heating.
\end{abstract}

Key words: Dealumination, metakaolin, reactor, dealuminator.

\section{INTRODUCTION}

Nigeria as a nation is faced with the challenges of harnessing her abundant solid mineral deposits for national development, and clay (kaolin) has been confirmed to have a prominent role to play in these developmental efforts [1]. A prominent kaolin process step that adds much value to this mineral is the dealumination step which splits the reactive phase of kaolin known as metakaolin to two major products, alumwhich contains the alumina component and silica. The cheap and abundant nature of kaolin and the fact that it is next to bauxite in alumina content had been given much attention [2]. In Nigeria particularly, there is no known commercial bauxite deposit. Nevertheless, kaolin clay is an alternative, containing $33-39 w t \%$ alumina content, which is abundantly available [3].Kaolinite clay commonly known as kaolin is a naturally occurring mineral with the chemical make-up of: $\mathrm{Al}_{2} \mathrm{Si}_{2} \mathrm{O}_{5}(\mathrm{OH})_{4}$. Clays are widely used as catalysts and catalyst supports for a quite broad range of processes. Clay catalysts have attracted much interest in catalytic application in petroleum refining industry [4].Heat of sulphonation of acid-water had been reported to solely sustain the dealumination reaction which ultimately enhance the energy economics of the process [5]. An earlier pilot size dealuminator to handle $1 \mathrm{~kg} / \mathrm{batch}$ was designed but had a lot of challenges with regard to the material selection for the reactor and components configuration of the dealumination unit [6], in this study, the challenges wereadequately addressed. The alum produced from the dealumination pilot unit could be used for various industrial applications such as water treatment, aluminum hydroxide preparation and alumina production. While the silica could find applications as catalyst support as well as recipe for the preparation of other useful silica based chemicals such sodium silicate and silica sol. The successes recorded for the production of zeolite Y and ZSM-5 from Kankara kaolin at the bench scale had given a morale boost for the production of these zeolites at a pilot scale, in which dealumination unit is a key fraction of zeolite production from kaolin. The products of dealumination unit are very useful for the zeolite recipe preparation. The pilot size became necessary in the quest to kick start zeolite $\mathrm{Y}$ and ZSM-5 production at industrial scale level from kaolin.

\footnotetext{
* Corresponding author, tel: +234 - $703-792-5411$
} 


\section{EXPERIMENTAL PROCEDURE}

\subsection{Design}

Basic and rational engineering principles, calculation and intuition which resulted to series of equations were used for the design. Basis of $2.5 \mathrm{~kg}$ metakaolin per batch was used, the average percentage of the alumina content in the metakaolin was the determining factor for the reactor size from the equations generated. The dealumination unit comprises of;

i. Dealumination reactor (dealuminator)

ii. Metakaolin slurry mixing tank, and

iii. Acid holding tank

\subsubsection{Dealumination Reactor (Dealuminator):}

Batch reactor model was chosen for the design of the dealuminator. Average alumina content from several Xray Fluorescence (XRF) analysis $=40 \%$. The basic dealumination equation and the material balance are shown in Equation (1) and Table 1 respectively. While the flow of materials into and out of the dealuminator is shown in Figure 1.

Volume of Dealumination Reactor

Average density

$$
\bar{\rho}_{\text {reactants }}=\frac{\sum_{i=1}^{3} \rho_{i} X_{i}}{\sum_{i=1}^{3} X_{i}}=\frac{1.315}{1}=1.315
$$

Volume of dealuminator

$$
V_{d *}=\frac{M_{T}}{\rho_{\text {reactants }}}=\frac{31340}{1.315}=23832.70 \mathrm{~cm}^{3}
$$

In order to avoid much pressure build up in the system, since the dealuminator is not being designed as a pressurized vessel and to also accommodate water vapour that will be generated at the initial stage of the reaction, which will occupy much space (basic properties of gases), a safety factor of $25 \%$ was chosen. The actual volume

$$
V_{d}=1.25 \times 23832.70=29791 \mathrm{~cm}^{3}
$$

The volume of the dealuminator $\left(V_{d}\right)$ was approximately: $30000 \mathrm{~cm}^{3}$

$$
\begin{array}{cccc}
\mathrm{Al}_{2} \mathrm{Si}_{2} \mathrm{O}_{7(\mathrm{~s})}+3 \mathrm{H}_{2} \mathrm{SO}_{4(l)} & \rightarrow \mathrm{Al}_{2}\left(\mathrm{SO}_{4}\right)_{3(l)} \cdot 3 \mathrm{H}_{2} \mathrm{O}+2 \mathrm{SiO}_{2(s)} & \\
\text { Metakaolin } & \text { Sulphuric acid } & \text { Alum } & \text { Silica }
\end{array}
$$

Table 1: Material balance around the dealumination reactor

\begin{tabular}{lrrrrr}
\hline & $\begin{array}{l}\text { Stream 1 } \\
\text { Metakaolin slurry }(\mathrm{g})\end{array}$ & $\begin{array}{l}\text { Stream 2 } \\
\text { Acid }(\mathrm{g})\end{array}$ & $\begin{array}{l}\text { Stream 3 } \\
\text { Quenching water }(\mathrm{g})\end{array}$ & $\begin{array}{l}\text { Stream 4 } \\
\text { Residue }(\mathrm{g})\end{array}$ & $\begin{array}{l}\text { Stream } 5 \\
\text { Alum }(\mathrm{g})\end{array}$ \\
\hline $\mathrm{Al}_{2} \mathrm{O}_{3}$ & 1000 & 0 & 0 & 20 & 0 \\
$\mathrm{SiO}_{2}$ & 1300 & 0 & 0 & 1287 & 13 \\
$\mathrm{H}_{2} \mathrm{O}$ & 4656 & 147.4 & 16645.86 & 4289.852 & 17159.408 \\
$\mathrm{H}_{2} \mathrm{SO}_{4}$ & 0 & 7150.374 & 0 & 357.5187 & 3932.7057 \\
$\mathrm{Al}_{\left(\mathrm{SO}_{4}\right)_{3}}$ & 0 & 0 & 0 & 0 & 3840.1496 \\
Impurities & 200 & 72.226 & 168.14 & 8.80732 & 431.55868 \\
Sub-Total & 7156 & 7370 & 16814 & 5963.17802 & 25376.82198 \\
Total & & & & & 31340 \\
& & 31340 & & &
\end{tabular}

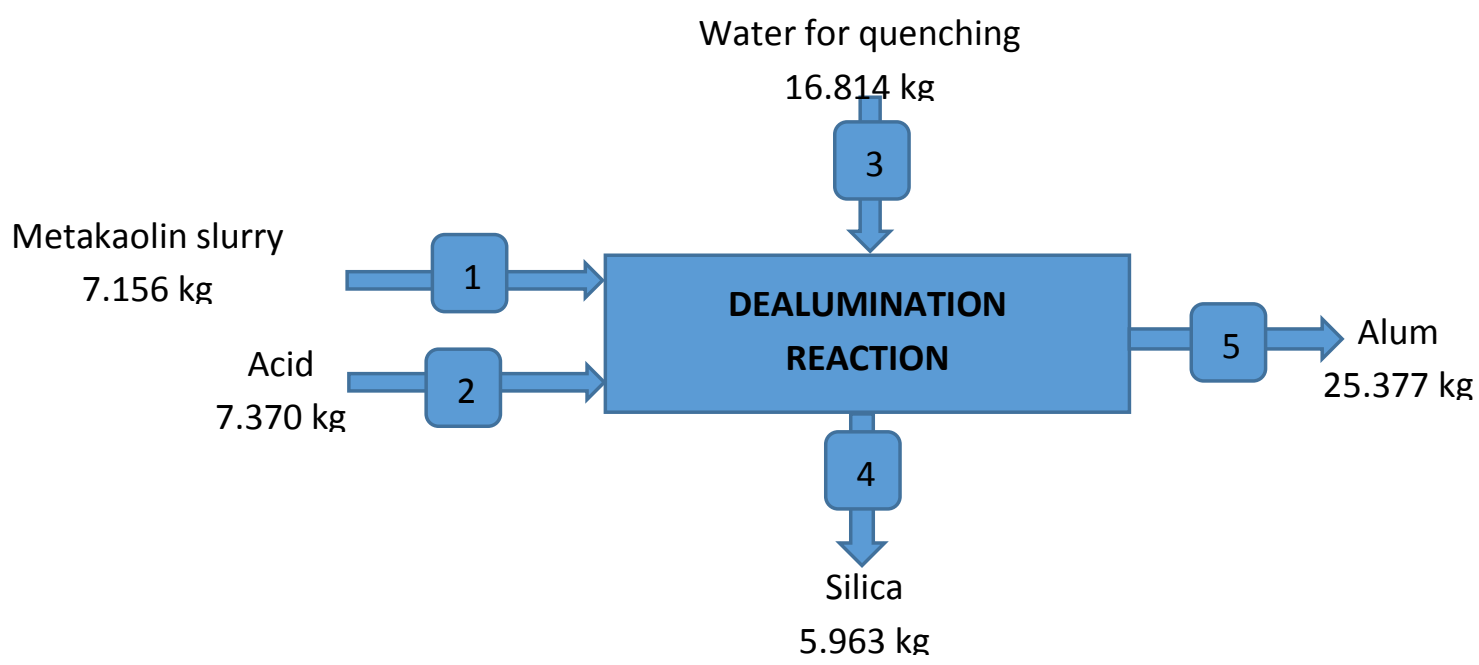

Figure 1: Material balance around the dealuminator 
The height $\left(H_{d}\right)$ to diameter $\left(D_{d}\right)$ ratio was taken as 2 , which is in agreement with literature [7] $H_{d}: 53.46 \mathrm{~cm}$ $D_{d}: 26.73 \mathrm{~cm}$

\section{Time of dealumination reaction}

Consideration of reaction kinetics developed for dealumination reaction [1],

$$
-r_{A l}=131.6 e^{\frac{-3837.8}{T}} C_{A c 0}
$$

The rate of dealumination was a first order reaction with respect to the leached alumina component, Evaluating the time of reaction for $95 \%$ conversion, the batch reactor performance equation was used:

$$
\begin{aligned}
& t=N_{A 0} \int_{0}^{X_{A}} \frac{d X_{A}}{\left(-r_{A l}\right) V} \\
& t=\frac{N_{A 0}}{V} \int_{0}^{X_{A}} \frac{d X_{A}}{\left(-r_{A l}\right)} \\
& t=C_{A l 0} \int_{0}^{X_{A}} \frac{d X_{A}}{\left(-r_{A l}\right)}
\end{aligned}
$$

$-r_{\mathrm{A}}$ : Rate of dealumination (g alumina/g metakaolin) (min) ${ }^{-1} ; \mathrm{C}_{\mathrm{Al}}$ : Concentration of alumina left in the raffinate (g alumina/g metakaolin); $\mathrm{C}_{\mathrm{Ac} 0}$ : Acid $\left(\mathrm{mol} / \mathrm{dm}^{3}\right)=9.066$; $\mathrm{T}$ : Reaction temperature $(\mathrm{K})=373$; Assuming conversion of 95\%; The pre-exponential factor is 131.6 $\mathrm{dm}^{3} /(\operatorname{mol~min})$;

In terms of conversion the rate of dealumination is expressed as:

$$
\begin{aligned}
& -r_{A l}=131.6 e^{\frac{-3837.8}{T}} C_{A c 0} C_{A l 0}\left(1-X_{A l}\right) \\
& t=C_{A l 0} \int_{0}^{X_{A}} \frac{d X_{A}}{131.6 e^{\frac{-3837.8}{T}} C_{A c 0} C_{A l 0}\left(1-X_{A l}\right)} \\
& t=\frac{C_{A l 0}}{131.6 e^{\frac{-3837.8}{T}} C_{A c 0} C_{A l 0}} \int_{0}^{X_{A}} \frac{d X_{A}}{\left(1-X_{A l}\right)} \\
& t=14.573 \int_{0}^{0.95} \frac{d X_{A}}{\left(1-X_{A l}\right)} \\
& t=14.573 \times(-\ln (0.05)) \\
& t=43.66 \text { mins } \\
& q^{\prime}=\frac{2 \pi(0.535)(90)}{\frac{\ln \left(\frac{0.137}{0.135}\right)}{16.0958}+\frac{\ln \left(\frac{0.137+t_{g w}}{0.137}\right)}{0.0415}+\frac{\ln \left(\frac{0.139+t_{g w}}{0.137+t_{g w}}\right)}{273}} \\
& 46.58=\frac{302.5746}{0.0000914+\frac{\ln \left(\frac{0.137+t_{g w}}{0.137}\right)}{0.0415}+\frac{\ln \left(\frac{0.139+t_{g w}}{0.137+t_{g w}}\right)}{273}} \\
& 24.096 \ln \left(\frac{0.137+t_{g w}}{0.137}\right)+0.003663 \ln \left(\frac{0.139+t_{g w}}{0.137+t_{g w}}\right)=6.4957 \\
& t_{g w}=0.042389 \mathrm{~m}=4.24 \mathrm{~cm}
\end{aligned}
$$

$d_{g w}=$ Thickness of the glass wool (lagging thickness); $r_{4}=\left(13.9+d_{g w}\right) c m=\left(0.139+d_{g w}\right) m ; \quad \Delta T \approx 393-$

$$
L=53.5 \mathrm{~cm} \approx 0.535 \mathrm{~m}
$$

Where $q^{\prime}=$ energy flow per unit time; $k_{a}=$ thermal conductivity of material a; $L=$ height of the cylinder; $r_{1}$ is the inner radius of the stainless steel; $r_{2}$ is the inner radius of the glass wool; $r_{3}$ is the inner radius of the aluminum casing; $r_{4}$ is the outer radius of the aluminum casing, $\mathrm{Ks}=16.0958 \mathrm{~W} / \mathrm{mK} ; \mathrm{Kw}=0.0415 \mathrm{~W} / \mathrm{mK} ; \mathrm{Ka}=$ $273 \mathrm{~W} / \mathrm{mK} ; \quad r_{1}=0.135 \mathrm{~m} ; \quad r_{2}=0.137 \mathrm{~m} ; \quad r_{3}=$

$m_{\text {total }}$ : total mass of the reacting system; $C p_{a v}$ : avearage specific heat capacity; $\Delta T$ : temparature difference; $\mathrm{Ti}$ is the initial temperature of the reacting system during dealumination; $T_{f}$ is the final temperature of the reacting system just before quenching; $t$ is the time for the dealumination reaction, $t=43.33$ minutes:

$$
\begin{gathered}
q^{\prime}=\frac{14.526 \times 4200 \times 2}{43.66 \times 60}=46.58 \mathrm{~W} \\
q^{\prime}=\frac{2 \pi L \Delta T_{\text {overall }}}{\frac{\ln \left(\frac{r_{2}}{r_{1}}\right)}{k_{s}}+\frac{\ln \left(\frac{r_{3}}{r_{2}}\right)}{k_{w}}+\frac{\ln \left(\frac{r_{4}}{r_{3}}\right)}{k_{a}}}
\end{gathered}
$$

Determination of insulating material thickness
Glass-wool was chosen as the insulating material, its thickness round the reactor to minimize heat loss to the surrounding was evaluated as follow: Required design model:

$$
q^{\prime}=\frac{m_{\text {total }} C p_{a v} \Delta T}{t}
$$




\subsubsection{Metakaolin Slurry Tank}

The metakaolin slurry tank was the chamber where the metakaolin was mixed with water before being channeled into the dealuminator. The quantity of materials in the mixing tank is presented in Table 2.

Table 2: Parameters for metakaolin slurry components

\begin{tabular}{lccccc}
\hline Reactants & $\begin{array}{l}\text { Volume } \\
\left(\mathrm{cm}^{3}\right)\end{array}$ & $\begin{array}{c}\text { Density } \\
\left(\mathrm{g} / \mathrm{cm}^{3}\right)\end{array}$ & $\begin{array}{l}\text { Mass } \\
(\mathrm{kg})\end{array}$ & $\begin{array}{c}\text { Fractional } \\
\text { composition } \\
X_{i}\end{array}$ & $\begin{array}{c}\rho_{i} X_{i} \\
\mathrm{~g} / \mathrm{cm}^{3}\end{array}$ \\
\hline Water & 4656 & 1.00 & 4.656 & 0.65 & 0.650 \\
Metakaolin & 1000 & 2.50 & 2.500 & 0.35 & 0.875 \\
& & & 7.156 & & 1.525 \\
\hline
\end{tabular}

$$
\rho_{\text {slurry }}=\frac{\sum_{i=1}^{n} \rho_{i} X_{i}}{\sum_{i=1}^{n} X_{i}}=\frac{1.525}{1}=1.525 \mathrm{~g} / \mathrm{cm}^{3}
$$

Where $\rho_{i}=$ density of component I; $X_{i}=$ mass fraction of component $\mathrm{i}$

$$
\begin{gathered}
V_{m T}=4692.459 \mathrm{~cm}^{3} \\
V_{A c m T}=1.25 V_{m T}
\end{gathered}
$$

Actual required volume $\left(V_{A c m T}\right) \quad$ was $V_{A c m T}=$ $5865.574 \mathrm{~cm}^{3}$

The slurry tank was also used as the channel through which the water for quenching was introduced into the dealumination reactor (dealuminator) at the end of the reaction. Volume of water for reaction quenching was calculated as: $16814 \mathrm{~cm}^{3}$, the total volume required for the metakaolin slurry tank was taken as: $V_{A c m T}^{*}=$ $20,000 \mathrm{~cm}^{3}$

Power requirement of the motor for metakaolin slurry mixing

$$
N_{P}=f(R e, F r)
$$

Where: $N_{P}=$ Power number

$$
\text { Re }=\text { Reynolds number } R e=\text { Froude number }
$$

Equation 13 then becomes:

$$
\frac{P}{\rho N^{3} D_{T}{ }^{5}}=f\left(\frac{\rho N D_{T}{ }^{2}}{\mu}, \frac{N^{2} D_{T}}{g}\right)
$$

For un-baffled tanks, at higher Reynolds number, a vortex $f$ and the Froude number has a significant effect on the power number[8]. The general equation is then modified

$$
\begin{gathered}
P=N_{p} \rho N^{3} D_{I}^{5} \\
P=1.446 \times 1525 \times(6.5)^{3} \times(0.1542)^{5}=52.80 \mathrm{~W}
\end{gathered}
$$

To compensate for transmission losses, frictional losses in the gear box and reduced efficiency of the electric motor, a safety factor of $25 \%$ was selected.

$$
\begin{gathered}
P_{a c t}=1.25 \times P_{\min } \\
P_{a c t}=1.25 \times 52.80 \\
P_{a c t}=66 \mathrm{~W}
\end{gathered}
$$

\subsubsection{Acid holding tank}

The tank is where the acid is kept before releasing it into the reactor for initiating the reaction when it come in contact with the homogenous metakaolin slurry.

Amount of acid needed per batch $=4,027 \mathrm{~cm}^{3}$

Allowing 20\% free board space, the actual volume of acid $\operatorname{tank}\left(V_{A T}\right)$ required is:

$$
V_{A T}=1.2 \times 4027=4,832.40 \mathrm{~cm}^{3}
$$

Considering cylindrical shape, with height diameter ration of 2, considering $5,000 \mathrm{~cm}^{3}$ as the volume of acid tank:The diagrammatic representation and projection drawings of the dealumination unit are shown in Figure 2.

\subsection{Material selection}

The reactor for the dealumination was made of stainless steel type 304 which withstands mild acidic environment. Because of the elevated temperature of the dealumination reaction, the inner chamber of the reactor was lined with glass. The lining helped in avoiding direct contact of the reacting species and the stainless steel part of the reactor. Both the acid tank and the metakaolin slurry mixing tank were made of plastics, which were cheaper and would not be attack by the reactants involved and were at room temperature.

But for the acid tank the appropriate type of plastic material to be use is polyethylene, rather than the material used in this work which was improvised.The piping and fittings were largely made of plastics where the temperature was not very high. A small fraction of the fittings were made of stainless steel material, especially parts that would experience high temperature.

\subsection{Fabrication and assembling}

The fabrication of the dealumination unit was done after the completion of the design and the selection of the appropriate materials for various components of the unit. It was assembled after fabrication. The instrumentation attached to the reactor include pressure gauge, pressure relief valve and temperature read-out.

\subsection{Test running}

The materials used for the reaction in other to test run the dealumination unit include:

1. Concentrated sulphuric acid, $98 w t \%$

2. Metakaolin, prepared from Kankara kaolin

3. Distilled water

The calculated amount of the sulphuric acid needed for the reaction of $2.5 \mathrm{~kg}$ of metakaolin was poured into the acid holding tank. The required amount of distilled water was poured into the metakaolin slurry tank. 

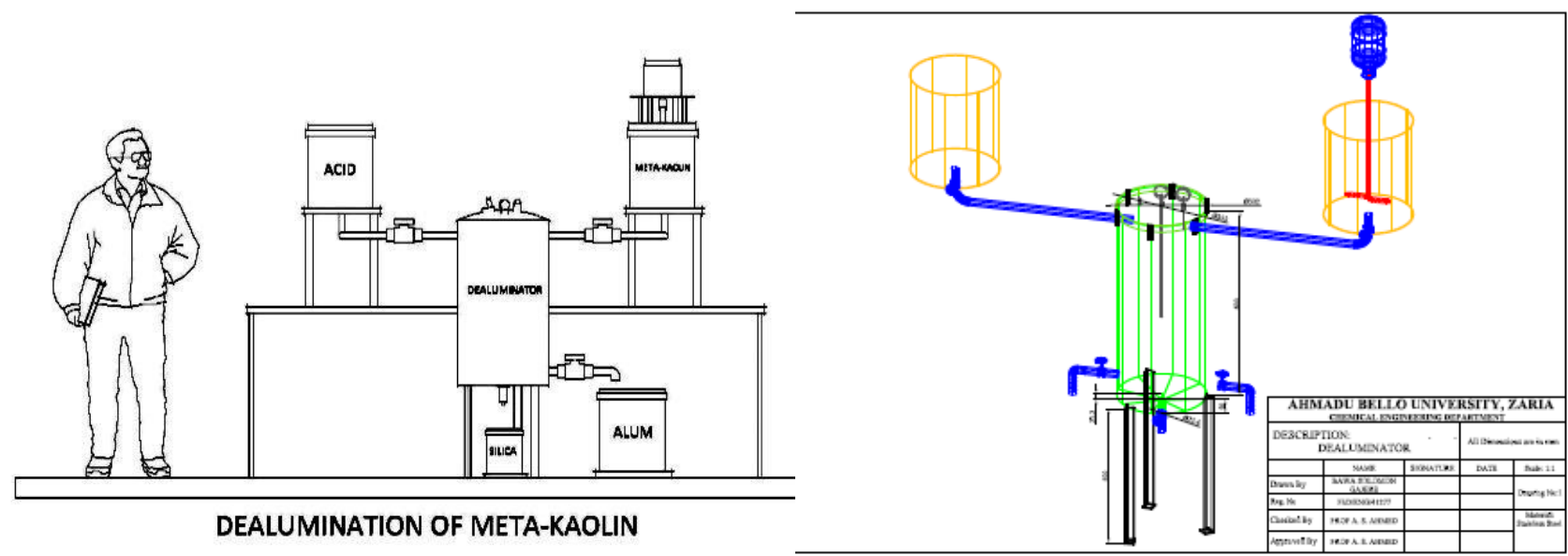

Figure 2: Diagrammatic representation of the dealumination unit of the pilot plant

The motor was switched on after which the metakaolin slurry was emptied into the mixing tank. After homogeneity was attained in the slurry mixing tank, the metakaolin slurry $(35 \%$ solid) was emptied into the dealumination reactor. The acid was then channeled into the dealumination reactor, in a controlled manner. The reaction began immediately and after 20 minutes the reaction was quenched by the addition of distilled water. The added water lowered the concentration of the acidic condition of the reaction from $60 \mathrm{wt} . \%$ to $30 \mathrm{wt} . \%$. The alum, which contained the leached alumina from the metakaolin and silica, which was inert to the acid were collected at the side and bottom outlets of the reactor respectively. The silica was washed to get rid of the excess acid on it and dried before being characterized.

\section{RESULTS AND DISCUSSION}

The design specifications of the components of the dealumination unit which was comprised of the reactor, acid holding tank and metakaolin slurring mixing tank are presented in Table 3.

\section{Table 3: Design specifications}

\begin{tabular}{cll}
\hline S/No. & Design parameters & Specifications \\
\hline 1. & Volume of reactor, VR & 50 liters \\
2. & Height of reactor, $\mathrm{H}$ & $60 \mathrm{~cm}$ \\
3. & Internal diameter of reactor & $30 \mathrm{~cm}$ \\
4. & Thickness & $2 \mathrm{~mm}$ \\
5. & Volume of acid holding tank & 5 liters \\
6. & Volume of metakaolin mixing tank & 10 liters \\
7. & Speed of impeller, $\mathrm{N}$ & $390 \mathrm{RPM}$ \\
8. & Density of metakaolin slurry & $1.51 \mathrm{~g} / \mathrm{cm}^{3}$ \\
9. & Viscosity of metakaolin slurry & $1.73 \times 10^{-2 P a} . \mathrm{S}$ \\
10. & Reynolds number of impeller, NRe & 4983 \\
11. & Power requirement & $70 \mathrm{~W}$ \\
12. & Insulating material & Fiber glass \\
13. & Thickness of insulating material & $14 \mathrm{~mm}$ \\
14. & Thickness of glass lining & $4 \mathrm{~mm}$ \\
15. & Rate of heat loss & $21.5 \mathrm{~W}$ \\
\hline
\end{tabular}

The assembled unit is as shown in Plate 1.

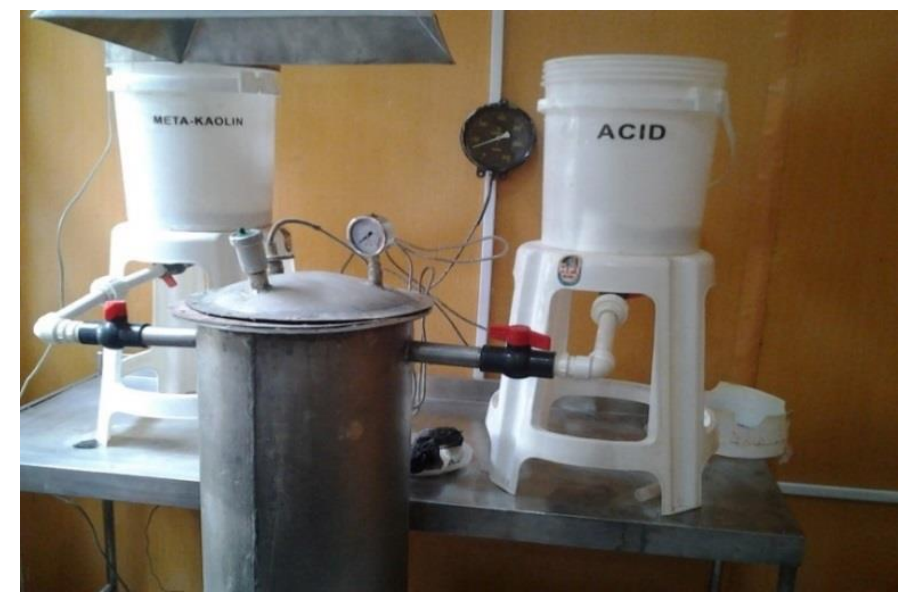

Plate 1: Dealumination unit

Table 4: Chemical composition of metakaolin and dealumination product

\begin{tabular}{lcccccc}
\hline Oxides & $\mathrm{SiO}_{2}$ & $\mathrm{Al}_{2} \mathrm{O}_{3}$ & $\mathrm{Na}_{2} \mathrm{O} / \mathrm{K}_{2} \mathrm{O}$ & $\mathrm{Fe}_{2} \mathrm{O}_{3}$ & $\mathrm{CaO}$ & $\mathrm{MgO}$ \\
\hline Metakaalin & 59.52 & 36.55 & 1.06 & 0.94 & 0.53 & 0.18 \\
Silica (Lab. & 93.54 & 1.88 & 2.64 & 0.12 & 0.24 & 0.28 \\
Scale) & 86.15 & 2.60 & 5.15 & 0.71 & 0.50 & 0.48 \\
Silica (Run 1) & 96.5 & $\mathrm{ND}^{*}$ & 1.20 & 0.23 & 0.18 & $\mathrm{ND}^{*}$ \\
Silica (Run 2) & 96.20 & & & &
\end{tabular}

The metakaolin had two major components namely, alumina and silica, which accounted for $96.07 \%$ (Table 2 ) of the metakaolin. The molar ratio of silica to alumina was found to be 2.4 , the value was above 2 , which is reported in literature [9], owing to the fact that the $59.52 \%$ of silica was for both the structural and free silica in the metakaolin. The first run (before lining with glass) of dealumination reactor gave $86.15 \%$ of silica, at that initial stage leaching of the surface of the inner part of the reactor being stainless steel type 304 occurred. Part of the energy that supposed to be used for the dealumination process was used-up on leaching of the iron content of the stainless steel. At the second run, the percentage of silica obtained was $96.5 \%$ which was

Vol. 36, No. 3, July 2017 
better than the laboratory dealumination of $93.54 \%$ silica content as shown in Table 2 . This observation could be attributed to the minimal heat loss to the environment, more so, no observable leaching occurred. The glass lining helped in preserving the heat for maximal unlocking of the alumina from the metakaolin and leaving the silica as the residue of the reaction. The external lagging reduced the heat loss to the environment, as such more heat was conserved in the reactor that boast the extent of dealumination. The weight percentage of silica in metakaolin of about $59 \%$ increased after the dealumination reaction for both the laboratory and pilot scale, as shown in Figure 2. When the dealumination reactor was completely lined at stage 2 , in Figure 2, the extent of leaching of the alumina component was better than the laboratory scale. This observation could be attributed to the amount of energy of hydration generated when the acid was in contact with the metakaolin slurry in the dealumination reactor.

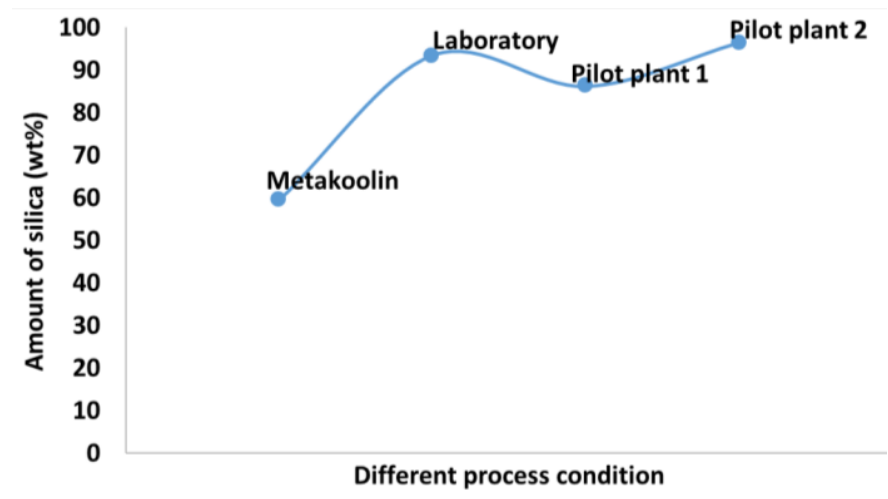

Figure 2: Amount of silica in the dealumination residue

\section{CONCLUSIONS}

Dealumination unit which comprised of dealumination reactor, acid holding tank and metakaolin slurry mixing tank was successful designed, fabricated and test-run. The materials selected for the fabrications were stainless steel Type 304, glass lining for reactor internal part, woven glass fiber and plastics which were suitable during usage. The alum and silica produced where good, the quality of the later was higher than the one obtained from the laboratory. It is anticipated that this work will promote large scale industrial production of metakaolin which is a chemical intermediate for zeolite production, hence will engender socio- economic development of nations with abundant kaolin resource such as Nigeria.

\section{ACKNOWLEDGEMENTS}

The authors are grateful to Petroleum Technology Development Fund (PTDF) Abuja for funding the research work.

\section{REFERENCES}

[1] Aderemi, B. O., Oloro, E. F., Joseph, D. and Oludipe, J."Kinetics of Dealumination of Kankara Kaolin Clay", Nigerian Journal of Engineering, Vol. 9, Number 1, pp 40-44, 2001.

[2] Edomwonyi-Otu, L., Aderemi, B. O. and Ahmed, A. S. "Beneficiation of Kankara Kaolin for Alum Production", Nigerian Journal of Engineering, Vol. 16, Number 2, 2010, pp 27-35.

[3] Raw Material Research and Development Council Publication. "Raw Materials and Consumer Industries in Nigeria", www.rmrdc.org, Accessed on July 13, 2012.

[4] Emam, E. A. "Clays as Catalysts in Petroleum Refining Industry", ARPN Journal of Science and Technology, Vol. 3, Number 4, pp 357-375, 2013.

[5] Ajayi, A. O., Atta, A. Y., Aderemi, B. O., Adefila, S. S. "Novel Method of Metakaolin Dealumination Preliminary Investigation", Journal of Applied Sciences Research, Vol. 6, Number 10, pp 15391546, 2010.

[6] Dickson, U. O., Jibrin, S., Christian, E. and Aderemi, B. O. "Design and fabrication of a pilot size ( $1 \mathrm{~kg}$ per batch) kaolin dealuminator for alum production", Nigerian Society of Chemical Engineers Conference on Harnessing Water Resources for National Development (The Role of Chemical Engineering), Abuja, Nigeria, November, 15-17, pp 63-64, 2012.

[7] Perry, R. H. and Green, D. W. Perry's Chemical Engineer's Handbook. $8^{\text {th }}$ Edn., McGraw - Hill Inc, New York, 2008.

[8] McCabe, W. L. and Smith, J. C. Unit Operations of Chemical Engineering $5^{\text {th }}$ Edn., McGraw- Hill Book Co., Singapore, 1993.

[9] Edomwonyi-Otu, L., Bawa, S. G. and Aderemi, B. O. , Effect of Beneficiation of KaolinRaw Material on Alumina Yield and Quality, Nigerian Journal of Engineering, Vol. 16, Number 2, pp 36-43,2010. 